\title{
Carbon monoxide poisoning - rescue procedure
}

\section{Zatrucie tlenkiem węgla - postępowanie ratownicze}

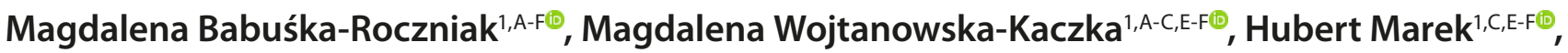

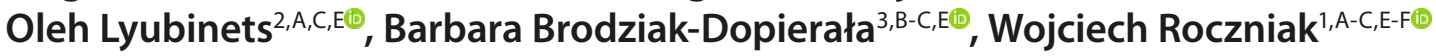

${ }^{1}$ The Jan Grodek State University in Sanok, Poland

${ }^{2}$ Danylo Halytsky Lviv National Medical University, Lviv, Ukraine

${ }^{3}$ Department of Toxicology and Bioanalysis, School of Pharmacy with the Division of Laboratory Medicine, Medical University of Silesia, Sosnowiec, Poland

A - Research concept and design, B - Collection and/or assembly of data, C - Data analysis and interpretation, $D$ - Writing the article, $E$ - Critical revision of the article, $F$ - Final approval of article

Babuśka-Roczniak M, Wojtanowska-Kaczka M, Marek H, Lyubinets O, Brodziak-Dopierała B, Roczniak W. Carbon monoxide poisoning - rescue procedurę. Med Og Nauk Zdr. 2020; 306-308. doi: 10.26444/monz/122852

\section{Abstract}

Introduction. Carbon monoxide is known as the 'silent killer'. It may lead to a direct threat to people' s life. In the statistics, carbon monoxide poisoning is in the third place after drugs and alcohol. Its victims are not only the result of accidents, but also because of deliberate action (suicide). There are many emergency medical interventions in cases of carbon monoxide poisoning.

Objective. The aim of the study was to determine the appropriate scheme for medical rescue teams attending to the victim poisoned by carbon monoxide.

Materials and method. The research material was obtained from the analysis of medical record cards of rescue actions and the order of departure medical rescue team, which were directed to 70-year-old man due to carbon monoxide poisoning as a result of intentional action - a suicide attempt. The case study method was used.

Results. Most important for the medical person assisting in a case of poisoned by carbon monoxide is the immediate interruption of exposure to the toxic gas by evacuation of the victim, and quick implementation of a high rate of oxygen flow. In such a situation, each minute is very precious. The longer the exposure to the fumes, the less likely the victim is to survive.

Conclusions. The medical rescue team acted in accordance with the guidelines in a case of carbon monoxide poisoning. They properly implemented the medical rescue operation, but this does not always guarantee success.

\section{Key words}

poisoning, carbon monoxide, emergency procedures, emergency medical teams

\section{Streszczenie}

Wstęp. Tlenek węgla określany jest mianem „cichego zabójcy”. Stanowi bezpośrednie zagrożenie dla życia poszkodowanego. W statystykach zatrucia czadem zajmują trzecie miejsce tuż po lekach i alkoholu. Jego ofiarami są poszkodowani na skutek nie tylko nieszczęśliwych wypadków, ale również celowego działania (samobójstw). Jest częstą przyczyną interwencji zespołów ratownictwa medycznego.

Cel pracy. Celem pracy było określenie właściwego schematu postępowania zespołów ratownictwa medycznego wobec poszkodowanego, który uległ zatruciu tlenkiem węgla.

Materiał i metody. Materiał badawczy pozyskano z analizy karty medycznych czynności ratunkowych oraz zlecenia wyjazdu zespołu ratownictwa medycznego, który został zadysponowany do 70-letniego mężczyzny z powodu zatrucia tlenkiem węgla na skutek celowego działania - próby samobójczej. W badaniu wykorzystano metodę studium indywidualnego przypadku.

Wyniki. Priorytetem w udzielaniu pomocy medycznej osobie zatrutej tlenkiem węgla jest niezwłoczne przerwanie ekspozycji na toksyczny gaz poprzez ewakuację z miejsca zdarzenia oraz jak najszybsze wdrożenie tlenoterapii o dużym przepływie. Ogromną rolę odgrywa upływający czas. Im dłuższa ekspozycja na czad, tym mniejsze szanse poszkodowanego na przeżycie. Wnioski. Zadysponowany zespół ratownictwa medycznego postępował zgodnie z obowiązującymi wytycznymi w przypadku zatrucia tlenkiem węgla. Poprawnie wdrożone medyczne czynności ratunkowe nie zawsze jednak gwarantują sukces.

\section{Słowa kluczowe}

zatrucie, tlenek węgla, postępowanie ratunkowe, zespoły ratownictwa medycznego
Addres for correspondence: Wojciech Roczniak, The Jan Grodek State University in Sanok, Poland

E-mail:wojciech_roczniak@interia.pl

Received: 08.04.2020; accepted: 26.05.2020; first published: 12.06 .2020

\section{INTRODUCTION}

Carbon monoxide (CO) is a colourless, odourless and highly toxic gas. It is formed as a result of incomplete combustion of many fuels, among them propane, kerosene, gasoline, oil, wood, oil, gas and coal [1]. The gas is slightly lighter than air at the same temperature, easily mixes with air in a closed room, and spreads quickly [2]. 
Carbon monoxide is referred to as 'silent killer'. Poisoning with this gas poses a direct threat to health and life. It contributes to many deaths both in Poland and worldwide. In the poisoning statistics, it ranks third immediately after drugs and alcohol, and is used in over $70 \%$ of suicides [3].

Carbon monoxide combines with haemoglobin to form carboxyhaemoglobin. The affinity of carbon monoxide alone for haemoglobin is 200-250 times greater than oxygen. Carboxyhaemoglobin dissociates 10 times more slowly than oxyhemoglobin. Carbon monoxide blocks haemoglobin for oxygen, which leads to tissue hypoxia $[4,5]$.

The symptoms of carbon monoxide poisoning vary depending on the percentage of carboxyhaaemoglobin in the blood. The following can be stated [6]:

Table 1. Symptoms of carbon monoxide poisoning

\begin{tabular}{lc}
\hline Symptoms & $\begin{array}{c}\text { Percentage of carboxyaemoglobin } \\
\text { in the blood }\end{array}$ \\
\hline no symptoms & $4 \%$ \\
\hline $\begin{array}{l}\text { vasodilation of the skin } \\
\text { temple pulsation and headache }\end{array}$ & $20-30 \%$ \\
\hline $\begin{array}{l}\text { nausea, daze, weakness, severe headache, } \\
\text { possible collapse }\end{array}$ & $30-40 \%$ \\
\hline $\begin{array}{l}\text { tachycardia, arrhythmias, nausea, daze, } \\
\text { weakness, severe headache and collapse }\end{array}$ & $40-50 \%$ \\
\hline $\begin{array}{l}\text { coma interrupted by convulsions } \\
\text { circulatory - respiratory failure, coma } \\
\text { interrupted by convulsions, possible death }\end{array}$ & $50-60 \%$ \\
\hline $\begin{array}{l}\text { respiratory depression, filiform pulse } \\
\text { and death }\end{array}$ & $70-80 \%$ \\
\hline
\end{tabular}

Source: own study based on [6].

\section{OBJECTIVE}

The aim of the study was to determine the appropriate pattern of actions of emergency medical teams when dealing with a person poisoned by carbon monoxide.

\section{MATERIALS AND METHOD}

The research material was obtained by analysing medical rescue cards and the order for departure of an emergency medical team dispatched to a 70 -year-old man suffering from carbon monoxide poisoning as a result of suicide attempt. The method of an individual case study was used.

\section{CASE REPORT}

The Specialist Team composed of two paramedics, including a driver and a system doctor, dispatched to intervene with a 70 -year-old man who was a suspected suicide victim. The dispatcher s report showed information that a neighbour had called an ambulance as he was concerned about a note on the door of the apartment informing about a gas leak. It was clear evident from the content that the note had been written by the victim to inform other residents of the danger. The emergency medical team arrived at the scene within eight minutes.
On arriving at the scene, the paramedics met the State Fire Service who undertook activities aimed at eliminating the threat of escaping carbon monoxide, and taking actions to save the life and health of the victim by removing him from the apartment and rendering it safe. According to the records of the team of paramedics, the victim was unconscious according to the AVPU scale (A - Alert; V - Verbal; P Pain; U - Unresponsiv) and on the GCS (Glasgow Coma Scale) - 3 points. An examination according to the $A B C$ scheme was started: A - airway - unobstructed, B - breath - no breath within 10), at the same time C - circulation no pulse detected. Cardiac arrest was stated. An indirect heart massage and ventilation with a self-reinflating bag was immediately started using a face mask connected to an oxygen source with a flow of $15 \mathrm{l} / \mathrm{min}$. The victim was monitored using a Lifepak 15 defibrillator and Quik-Combo adhesive electrodes. Rhythm assessment showed ventricular fibrillation. $200 \mathrm{~J}$ defibrillation was performed. During the first cardiopulmonary resuscitation (CPR) loop, endotracheal intubation was performed and oxygen therapy with 100\% oxygen was started using a respirator.

The following ventilator parameters were set:

- $\mathrm{f}$ - frequency per minute (frequency) - 10;

- TV - tidal volume - $600 \mathrm{ml}$;

- MV - minute ventilation - 6 litres;

- PEEP - positive end-expiratory pressure - $5 \mathrm{~cm} \mathrm{H}_{2} \mathrm{O}$;

- I:E - inspiration:expiration ratio - 1:2;

- $\mathrm{P}_{\max }$ - peak pressure - $35 \mathrm{~cm} \mathrm{H}_{2} \mathrm{O}$;

- $\mathrm{FiO}_{2}$ - fraction of inspired oxygen - 1.0;

- Pulse oximeter connected - $\mathrm{SpO}_{2}$ indication- 100\%;

- Capnograph connected - $\mathrm{EtCO}_{2}$ indication -4-6 mmHg.

After another two minutes, cardiac rhythm was reanalysed - VF. A second $300 \mathrm{~J}$ defibrillation was performed. Intravenous $(18 \mathrm{G})$ puncture was obtained in the second CPR loop. Due to persistent ventricular fibrillation, a third 360 J defibrillation was performed. Pharmacological treatment was implemented: $1 \mathrm{mg}$ Adrenaline intravenously (iv), $300 \mathrm{mg}$ Amiodarone (iv), $500 \mathrm{ml}$ drip infusion $0.9 \% \mathrm{NaCl}$ (iv) Subsequent ventricular fibrillation showed persistent ventricular fibrillation. After the 5th defibrillation, $1 \mathrm{mg}$ of adrenaline (iv) and $150 \mathrm{mg}$ of Amiodarone (iv) were administered. CPR was continued for another 20 minutes with a rhythm analysis every 2 minutes and Adrenaline given every 3-5 minutes at a dose of $1 \mathrm{mg}$. Rhythm assessments still showed persistent ventricular fibrillation. Despite subsequent defibrillation and drug supply, spontaneous circulation (ROSC) did not return. After 30 minutes of CPR, asystole appeared on the monitor. During the rescue operations, attempts were made to exclude potentially reversible causes of sudden cardiac arrest (SCA).

4H:

- HYPOXIA - the patient was ventilated with $100 \%$ oxygen through a self-inflating bag followed by a respirator.

- HYPOVOLEMIA - liquid therapy used - $500 \mathrm{ml}$ 0.9\% $\mathrm{NaCl}$.

- HYPOTHERMIA - excluded. A temperature of $37.0^{\circ} \mathrm{C}$ on the tympanic membrane. The victim was not exposed to cold air, rain or wind.

- HYPO-/HYPERKALEMIA - to exclude such disorders, during pre-hospital assistance the level of glycaemia was measured to obtain a value of $137 \mathrm{mg} \%$ 
4 T:

- TAMPONADE - no visible injury penetrating the chest.

- TENSION PNEUMOTHORAX - no injury, symmetrical chest movements during ventilation, no ventilation resistance in the airways. Auscultally after intubation, the current vesicular murmur over the entire lungs.

- THROMBOSIS PULMONARY/CORONARY - no history to indicate the presence of thromboembolic disease.

- TOXINS - the toxic effect of carbon monoxide was indicated. A potentially reversible cause of SCA was diagnosed, the Advanced Life Support (ALS algorithm) was followed in special situations. $100 \%$ oxygen ventilation with positive airway pressure was used with intubation and respiratotherapy.

During the $\mathrm{CPR}$, the dispatcher was contacted regarding the availability of a hyperbaric chamber. The nearest was inaccessible due to the long distance (travel time to the chamber exceeded 90 minutes), and the use of an LPR helicopter was impossible due to bad weather.

Despite cardiopulmonary resuscitation, the team was unable to restore vital functions. After 45 minutes, the decision was made to discontinue emergency medical services by filling in an asystole confirmation protocol.

\section{DISCUSSION}

Rescue actions taken for people poisoned with carbon monoxide should be fast, coordinated and consistent with the algorithm.

I. Most often, people who have carbon monoxide poisoning are also victims of a fire. In such cases, the Fire Brigade is usually the first to arrive at the scene and are authorized to evacuate people from the danger zone. Providing safety for both the victim and members of the emergency medical team is the priority of the rescue operation.

II. If there is a suspicion that the victim in a room where the fire did not occur,it is permissible to undertake rescue actions, provided that air exchange is ensured by opening a window or door. It is safer for the emergency medical team if the victim is evacuated from the room and taken to a place of safety with the best access to constant fresh [1].

III. If the victim is unconscious, an optimal oxygen flow should be initiated at between $10-15 \mathrm{l} / \mathrm{min}$ [7].

IV. If the condition of the victim allows it, the rescue team should conduct an interview to collect information that would be useful for a quick and accurate diagnose. For this purpose, the SAMPLE interview is used to collect structured information about the victim.

V. If the victim is unconscious, the paramedics should check the airway and the presence of breath and pulse [8]. After proper breathing is found, action should be as in the case of a conscious person, passive oxygen therapy should be provided using an oxygen mask with a self-inflating bag. An oropharyngeal tube is recommended for an unconscious victim to ensure airway patency [9]. However, if the victim is not breathing, ALS should be taken as soon as possible. Early initiation of cardiopulmonary resuscitation increases the chances of survival $[8,10]$.

VI. The victim who removed from a burning building may be poisoned not only with carbon monoxide, but also with cyanide. Therefore, all precautions should be taken during ventilation, i.e. ventilation using a face mask and a self-inflating bag [11].

The medical rescue operations in the above-mentioned case were carried out in accordance with the developed and binding algorithm of conduct. The injured was evacuated from the danger zone by the State Fire Service, which enabled the emergency medical team to take safe actions. Immediately after the initial assessment and finding cardiac arrest, ALS activities were implemented in accordance with the European Resuscitation Council (ERC 2015) guidelines. $100 \%$ oxygen therapy was also provided as soon as possible. During cardiopulmonary resuscitation, reversible causes of cardiac arrest were also taken into account and eliminated.

Unfortunately, despite the correct rescue operations, the victim's vital functions could not be restored. The cause of death of the patient was acute carbon monoxide poisoning, and the medical assistance was ineffective because of the time elapsed between the victim's exposure to the poison gas and arrival of medical assistance. It should be emphasized that the delay was not due to the tardiness of the emergency services, but through the lack of direct witnesses to the incident who could have reacted earlier and summoned assistance.

\section{CONCLUSIONS}

The dispatched emergency medical team followed the applicable guidelines for carbon monoxide poisoning. Prompt arrival at the scene of an incident and attention by the medical emergency services greatly enhance the chance of survival of the victim.

\section{REFERENCES}

1. Nowak M, Kawecki M, Skotnicka J, Knefel G, Ryszkiel I. Zatrucia toksycznymi produktami spalania (CO) - medyczne i psychologiczne następstwa zatruć. In: Czerwona księga pożarów. Vol 1. CNBOP-PIB: Józefów 2016.

2. Groblewska K, Królikowska A, Zieliński E, Nurczyńska E, Telak J. Zatrucie tlenkiem węgla - zadania ratownika na miejscu zdarzenia. Bezpieczeństwo i Technika Pożarnicza. 2014; 2: 123-132.

3. Makles Z, Pośniak M. Sezon grzewczy rozpoczęty - zagrożenia czadem. Bezpiecz Pr Nauk Praktyka. 2009; 12: 13-15.

4. Nieścior M, Jackowska T. Zatrucie tlenkiem węgla. Postępy Nauk Med. 2013; 7: 519-522.

5. Skotnicka-Klonowicz G, Rutkowska A, Janota A, Lewartowska-Nyga D, Śmigielski J, Grochocińska P. Ostre zatrucia przypadkowe i celowe u dzieci i młodzieży w materiale Oddziału Klinicznego Medycyny Ratunkowej dla Dzieci USK nr 4 w Łodzi. Probl Hig Epidemiol. 2014; 95(2): 400-406.

6. Obara K, Budrewicz S, Waliszewska-Prasół M, Rojek A, Ejma M. Toksyczne uszkodzenie mózgu z dominującym zespołem pozapiramidowym i amnestycznym w następstwie zatrucia tlenkiem węgla Pol Przegl Neurol. 2017; 13(2): 82-87.

7. Osiński P. Tlenoterapia bierna. Kurier Strażacki. 2012; 145-146: 3-5.

8. Andres J. Wytyczne resuscytacji 2015. Polska Rada Resuscytacji, Kraków; 2016.

9. Gontko-Romanowska K, Panieński P, Mitkowska J, Ratajczak K, Sroczyński M. Zatrucie tlenkiem węgla u dzieci w latach 2010-2012. Hygeia Publ Health. 2014; 49(3): 624-627.

10. Kłys M. Toksykologia kliniczna w aspekcie historycznym i współczesnym. Przegl Lek. 2011; 68(8): 399-404.

11. Gucwa J, Ostrowski M. Zaawansowane zabiegi resuscytacyjne i wybrane stany nagłe. MP: Kraków; 2018. 